\title{
A cross-sectional analysis of falsified, counterfeit and substandard medicines in a low-middle income country
}

\author{
Daariimaa Khurelbat ${ }^{1}$, Gereltuya Dorj ${ }^{1 *} \mathbb{D}$, Bruce Sunderland², Tsetsegmaa Sanjjav1', Enkhtuul Bayarsaikhan', \\ Davaadagva Damdinjav', Gantuya Dorj ${ }^{3}$, Altantuya Jigjidsuren ${ }^{4}$, Oyun Lkhagvasuren ${ }^{4}$ and \\ Baasandorj Erdenetsetseg ${ }^{1}$
}

\begin{abstract}
Background: High prevalence of falsified, counterfeit and substandard medicines pose a threat to public health and treatment failure. This study aimed to investigate the quality of selected essential medicines available in Mongolia.

Methods: A cross-sectional study collected essential medicines from pharmacy outlets in Mongolia, during June and July, 2017. These products were then submitted for pharmacopoeial analysis and registration status.

Results: A total of 1770 samples from 118 pharmacy entities were purchased from wholesalers in urban and rural areas. Pharmacopoeial analysis found 179 (10.1\%) samples or eleven product groups were unacceptable. The prevalence of substandard locally produced medicines $(n=105,5.9 \%)$ was higher than imported equivalents [ $(n=74$, $4.17 \%, p=0.0001)]$. Approximately one-third of all unacceptable tests were related to assay $(n=73,30.8 \%)$ and weight variation. Of 1770 samples, 76 (4.3\%) were unregistered and the prevalence of unregistered samples was $3.8 \%$ in Ulaanbaatar city and $5.8 \%$ in rural areas, respectively.
\end{abstract}

Conclusions: This study has indicated that falsified and substandard medicines are prevalent in Mongolia. Considerable effort is required by regulatory authorities, private manufacturers, as well as importers to increase the quality of essential medicines in Mongolia.

Keywords: Essential medicine, Falsified and substandard medicines, Quality, Mongolia

\section{Background}

The availability of low quality and/or counterfeited pharmaceutical products is one of the major barriers to provide quality essential health care in developing countries $[1,2]$. Indeed it is also an issue in some highincome countries [3, 4].

According to the World Health Organization (WHO), substandard medicines also called "out of specification",

\footnotetext{
*Correspondence: gereltuya@gmail.com; gereltuya.dori@mnums.edu.mn ${ }^{1}$ School of Pharmacy, Mongolian National University of Medical Sciences, S. Zorig street, Ulaanbaatar, Sukhbaatar District 14210, Mongolia

Full list of author information is available at the end of the article
}

are authorized medical products that fail to meet their quality standards or specifications, or both. Unregistered medical products have not undergone an evaluation and obtained approval by the National Regulatory Authority for marketing. Falsified medical products deliberately/ fraudulently misrepresent their identity, composition or source [5].

Recently, Ozawa et al. completed a systematic review of 44 extracted prevalence studies, conducted in 25 different countries. The median prevalence of substandard/ counterfeit medicines was $28.5 \%$ (11-48\%) [6]. Comparable findings were also reported by the WHO in 2017

(c) The Author(s). 2020 Open Access This article is licensed under a Creative Commons Attribution 4.0 International License, which permits use, sharing, adaptation, distribution and reproduction in any medium or format, as long as you give appropriate credit to the original author(s) and the source, provide a link to the Creative Commons licence, and indicate if changes were made. The images or other third party material in this article are included in the article's Creative Commons licence, unless indicated otherwise in a credit line to the material. If material is not included in the article's Creative Commons licence and your intended use is not permitted by statutory regulation or exceeds the permitted use, you will need to obtain permission directly from the copyright holder. To view a copy of this licence, visit http://creativecommons.org/licenses/by/4.0/ The Creative Commons Public Domain Dedication waiver (http://creativecommons.org/publicdomain/zero/1.0/) applies to the data made available in this article, unless otherwise stated in a credit line to the data. 
[7] and in other studies [8-10]. Moreover, the WHO has estimated the cost to procure substandard and falsified medicines to be approximately US $\$ 30.5$ billion worldwide [7]. Substandard and falsified medicines impact the community at patient-level, and if antibiotics pose a risk of antimicrobial resistance, cause ineffective treatment outcomes and unnecessary increased cost and health burdens [11].

The WHO reported surveillance of antibiotic consumption data worldwide and Mongolia was one of the countries with the highest antibiotic consumption (64.4 DDD per 1000 inhabitants per day) [12]. A pilot study of counterfeit medicines in Mongolia was undertaken by the Ministry of Health $(\mathrm{MOH})$ of Mongolia and 3.5\% were considered possibly counterfeit [13]. A larger scale study at the nationwide level indicated a higher prevalence of $14.6 \%(13.2-17.8)$ in 2012. The mission of the National Medicines Policy of Mongolia (NMPM) is to provide continuously, equitable and adequate supplies of medications for individuals, health facilities and veterinary services which are effective, safe, of good quality and affordable; and to promote the rational use of medicines [14]. Nevertheless, despite the Government's efforts to achieve successful implementation of the NMPM [14], the situation has deteriorated with respect to availability $[15,16]$, quality $[13,17,18]$ and rational use $[19,20]$.

The current study aimed to perform a repeat survey to assess and compare the quality of current medicines, including those manufactured in Mongolia.

\section{Methods}

A cross-sectional study followed the WHO Guidelines on the "Conduct of Surveys of the Quality of Medicines" [21]. This methodology was adapted to the Mongolian context, in particular the selection of medicines and pharmacy entities.

\section{Quality analysis of samples Materials for quality assessment}

Quality assessment tests including (i) appearance, (ii) weight variation, (iii) hardness, (iv) friability, (v) disintegration time and (vi) assay were determined according to pharmacopoeial methods according to the origin of the product or specification requirements from the manufacturer. In Mongolia, several pharmacopeias including the Mongolian National Pharmacopoeia (MNP), developed in 2011 and other relevant documents such as British Pharmacopoeia (BP), Pharmacopeia of the People's Republic of China (CP), United States Pharmacopeia (USP) and European Pharmacopeia (EP) are accepted as quality control standards.

USP, BP and CP reference standards of acetylsalicylic acid, amlodipine, cefotaxime, cetirizine, ciprofloxacin, ibuprofen, metronidazole, omeprazole, and sildenafil citrate were generously donated by the manufacturers. These included Daewon Pharm Co. Ltd. (Seoul, Korea), Kyongbo Pharmaceutical Co., Ltd. (Seoul, Korea), Sigma Aldrich (USA), Alchemy Medicine Pvt. Ltd. (India), Aristo Pharmaceuticals (Bangladesh), Abaris Healthcare Pvt. (India), Aristo Pharmaceuticals (India), Truong Tho Pharma Isc (Vietnam), NCPC (China). All other chemicals were commercially available and of analytical grade.

\section{Assessment of quality}

Identification of assay impurities was performed by ThinLayer-Chromatography (TLC) initially [22, 23]. The system employed glass -backed $5 \times 10 \mathrm{~cm}$ silica gel 60 F254 plates (E. Merck, Darmstadt, Germany), development of appropriate mobile phases in standard TLC containers, detection of black fluorescence-quenched spots on a bright green background under $254 \mathrm{~nm}$ UV light and of brown spots in white light after dipping the plate in the appropriate solution contained in a plastic bag.

Any suspicious samples and their active ingredients were identified by HPLC using UV detection (ThermoFisher Scientific Ultimate 3000, US). HPLC analysis was completed by using ODS Hypersil $150 \times 4.6 \mathrm{~mm} 5 \mathrm{mkm}$ $\mathrm{C} 18 \mu \mathrm{m}$ column, UV $254 \mathrm{~nm}$ detector, flow rate: $1 \mathrm{ml} /$ min, and varying mobile phases depending on the pharmaceutical product.

Quality analysis for the collected samples was performed with reference to USP 36, BP 2013, 2015, CP 2015, national pharmacopeial monograph (NPM), the MNP 1st edition 2011 and registration documents. (Table 1).

The samples were analyzed between August 2017 and December 2017 in the Medicines Quality Control Laboratory, National Reference Laboratory for Food Safety, Generalized Agency for Specialized Inspection of Mongolia (GASI) of Mongolia. The Medicines Quality Control Laboratory, National Laboratory Reference Laboratory for Food Safety, GASI is accredited by the ANSI-ASQ in the field of testing [24].

All analyses of samples were completed within the expiry date for each pharmaceutical product and were stored according to storage requirements for each product immediately after collection.

\section{Visual inspection and registration status}

Visual inspection and registration verification of all samples was conducted in compliance with the WHO recommendations [25] and national regulations [14, 26, 27], .and samples were checked based upon a modified version of the 'Checklist for the visual inspection of medicines to identify suspicious drug products'. [28] These included evaluation of outer packaging, layout, print color, information regarding the registration number, batch number, manufacturing date and expiry data. A 
Table 1 Selected drugs and corresponding reference standards

\begin{tabular}{|c|c|}
\hline Name of the drug, dose, dosage form & $\begin{array}{l}\text { Reference } \\
\text { document }\end{array}$ \\
\hline Acetaminophen 500 mg/tab & $\begin{array}{l}\text { MNP-2011, } \\
\text { NPM-0152-2014, } \\
\text { NPM-0046-2013 }\end{array}$ \\
\hline Acetylsalicylic acid, 81 mg/tab & $\begin{array}{l}\text { BP-2013, } \\
\text { NPM-0114-2014 }\end{array}$ \\
\hline Amlodipine $10 \mathrm{mg} / \mathrm{tab}$ & $\begin{array}{l}\text { NPM-0026-2013, } \\
\text { USP-36, } \\
\text { Registration } \\
\text { document }\end{array}$ \\
\hline Amoxicillin $500 \mathrm{mg} / \mathrm{tab}$ & $\begin{array}{l}\text { BP-2013, } \\
\text { CP-2010, } \\
\text { MNP-2011, }\end{array}$ \\
\hline Cefotaxime $1.0 \mathrm{~g} /$ powder for injection & $\begin{array}{l}\text { BP-2013, } \\
\text { CP-2010, } \\
\text { NPM-42- } \\
\text { 0088298102, } \\
\text { NPM-0052-2013, } \\
\text { Registration } \\
\text { document, } \\
\text { USP-36 }\end{array}$ \\
\hline Cetirizine $10 \mathrm{mg} / \mathrm{tab}$ & $\begin{array}{l}\text { BP-2013, } \\
\text { CP-2010, } \\
\text { NPM-0224-2015, } \\
\text { Registration } \\
\text { document, } \\
\text { USP-36 }\end{array}$ \\
\hline Ciprofloxacin 500 mg/tab & $\begin{array}{l}\text { BP-2013, } \\
\text { CP-2010, } \\
\text { MNP-2011, } \\
\text { USP-36 }\end{array}$ \\
\hline $\begin{array}{l}\text { Citramon-P (Acetylsalicylic } \\
\text { acid+acetaminophen+caffeine), } 450 \mathrm{mg} / \mathrm{tab}\end{array}$ & $\begin{array}{l}\text { MNP-2011, } \\
\text { NPM-0152-2014, } \\
\text { NPM-0154-2014 }\end{array}$ \\
\hline Diclofenac sodium $100 \mathrm{mg} / \mathrm{tab}$ & $\begin{array}{l}\text { BP-2013, } \\
\text { CP-2010, } \\
\text { MNP-2011, } \\
\text { NPM-023-2015, } \\
\text { NPM-0270-2016, } \\
\text { NPM-0115-2014 }\end{array}$ \\
\hline Ibuprofen, $400 \mathrm{mg} / \mathrm{tab}$ & $\begin{array}{l}\text { BP-2013, } \\
\text { BP-2015, } \\
\text { Registration } \\
\text { document }\end{array}$ \\
\hline Metronidazole $0.5 \% / 100 \mathrm{ml}$ infusion solution & $\begin{array}{l}\text { CP-2010, } \\
\text { Registration } \\
\text { document, } \\
\text { USP-36, }\end{array}$ \\
\hline Nystatin 500,000 IU/tab & $\begin{array}{l}\text { BP-2013, } \\
\text { USP-36, } \\
\text { Registration } \\
\text { document }\end{array}$ \\
\hline Omeprazole 20 mg/capsule & $\begin{array}{l}\text { BP-2013, } \\
\text { Registration } \\
\text { document }\end{array}$ \\
\hline $\begin{array}{l}\text { Panangin (Aspartic Acid, L- potassium and magnesium), } \\
298 \mathrm{mg} / \mathrm{tab}\end{array}$ & $\begin{array}{l}\text { Registration } \\
\text { document }\end{array}$ \\
\hline Sildenafil citrate $100 \mathrm{mg} / \mathrm{tab}$ & $\begin{array}{l}\text { NPM-0254-2016, } \\
\text { Registration } \\
\text { document }\end{array}$ \\
\hline
\end{tabular}

Note: $B P$ British Pharmacopeia, $C P$ Chinese Pharmacopeia, $M N P$ Mongolian National Pharmacopeia, NPM National Pharmacopeial Monograph, USP United States Pharmacopeias catalogue containing photographs of samples, packaging and package inserts was prepared. Moreover, information regarding the labelling of packages and containers was assessed against a national database, "Licemed" which is maintained and updated by the Center for Health Development, Ministry of Health, Mongolia [29]. The online database "Licemed" contains information regarding the status of registration of pharmaceutical products, in addition photographic images of genuine products registered in Mongolia. In addition, the license status of marketing authorization holders until 31st of January, 2018 of each sample was confirmed by Licemed [29].

Samples with suspicious packaging and labeling were sent to the representative offices in Mongolia of the manufacturers for confirmation whether if the suspected product was their product and discrepancies between the suspected and genuine product were verified.

\section{Site selection}

The study collection sites were divided into two areas: Ulaanbaatar city (the sole urban area) and the rural area. The rural area was divided into four geographical regions, namely Western, Central, Khangai, and Eastern region. From each region, one province was chosen accounting for the risk of transportation of unregistered, falsified and substandard medicines through borders and entry ports between Russia and China, including Bayanulgii, Dornogovi, Khuvsgul and Dornod provinces [30]. (Fig. 1).

As for the urban area, four districts, including Songinokhairkhan, Bayanzurkh, Sukhbaatar, Chingeltei, were conveniently selected in Ulaanbaatar and the selection was based on population size and health statistics [31].

\section{Selection of pharmacy entities}

A random method was employed to select the pharmacy entities in these geographical regions. The number of each type of pharmaceutical operations to be included in each region was weighted by the proportion of types of pharmacy entities in that geographic region. Pharmacy entities were selected using a random sample calculator. If the sample could not be obtained from the selected pharmacy entities, another pharmacy entity was randomly selected and substituted in order to make up the required numbers. The list of licensed pharmacy entities was obtained from the General Health Department of Ulaanbaatar city and GASI.

\section{Selection of medicines}

Medicines to be sampled were selected based on discussions with local experts. Specific criteria included that the medicines were included in the Essential Medicine's List of Mongolia (EML) [32], had been found 
substandard in previous studies [18], commonly prescribed and dispensed medicines with reimbursement from the health insurance office [33]. Their availability at all types of pharmacy entities, of high therapeutic importance and cost was considered. The medicines selected for sampling were: acetaminophen $500 \mathrm{mg}$ tablets; acetylsalicylic acid $81 \mathrm{mg}$ tablets; amlodipine $10 \mathrm{mg}$ tablets; amoxicillin $500 \mathrm{mg}$ tablets; cefotaxime $1 \mathrm{~g}$ vials; cetirizine $10 \mathrm{mg}$ tablets; ciprofloxacin $500 \mathrm{mg}$ tablets; citramon-P (acetylsalicylic acid+acetaminophen+caffeine) $450 \mathrm{mg}$ tablets; diclofenac sodium $100 \mathrm{mg}$ tablets; ibuprofen $400 \mathrm{mg}$ tablets; metronidazole $0.5 \% / 100 \mathrm{ml} /$ infusion; nystatin $5.000 .000 \mathrm{IU}$ tablets; omeprazole $20 \mathrm{mg}$ tablets; panangin (aspartic acid, L- potassium and magnesium) $298 \mathrm{mg}$ tablets and sildenafil citrate $100 \mathrm{mg}$ tablets.

\section{Sampling}

Data relating to the collected samples was recorded in pre-developed data collection forms [21, 28] and it included information of the contents of the medicine packages and the pharmacy entity. Sample collection from urban and rural areas was conducted during June and July of 2017 by two teams. In accordance with the WHO guidelines [21], each team consisted of a principal investigator, a locally recruited sampling researcher and an assistant. All members were trained in relation to purchasing the sample medicines according to the sampling procedure. Purchasing medicines and completing sampling forms for the individual medicines was performed by the sampling personnel.
Required numbers of samples of selected medicines were purchased from each pharmacy entity and if the sample was not available in stock, another pharmacy entity was recruited for the study.

All pharmacy entities were coded with a unique number and labeled with the same international nonproprietary name, brand name, strength, size, batch/lot number, and manufacturing and expiry dates for each sample. All containers and packages of medicines were also collected and preserved for confirmation purposes. Samples were maintained as per storage requirements, at $20-25^{\circ} \mathrm{C}$ (or as stated on the product) until analysis.

\section{Sample size calculation}

Based on a previous study of falsified/substandard drugs in Mongolia [18], the targeted sample size was to detect at least a $10 \%$ prevalence (alpha of 0.05 and beta of 0.9 ) accuracy. This calculation indicated that 20-30 samples of each drug (300-450 for all drug types combined) from each pharmacy entity were required for this study.

\section{Data analysis}

All data were entered into Microsoft Excel and IBM SPSS Statistics for Windows, version 20 (IBM Corp., Armonk, N.Y., USA). Categorical data were compared by means of Chi-square tests or Fisher's exact tests. $P$ values $<0.05$ were considered as statistically significant.

\section{Results}

A total of 1770 samples were purchased from 118 pharmacy entities a majority of which were obtained from

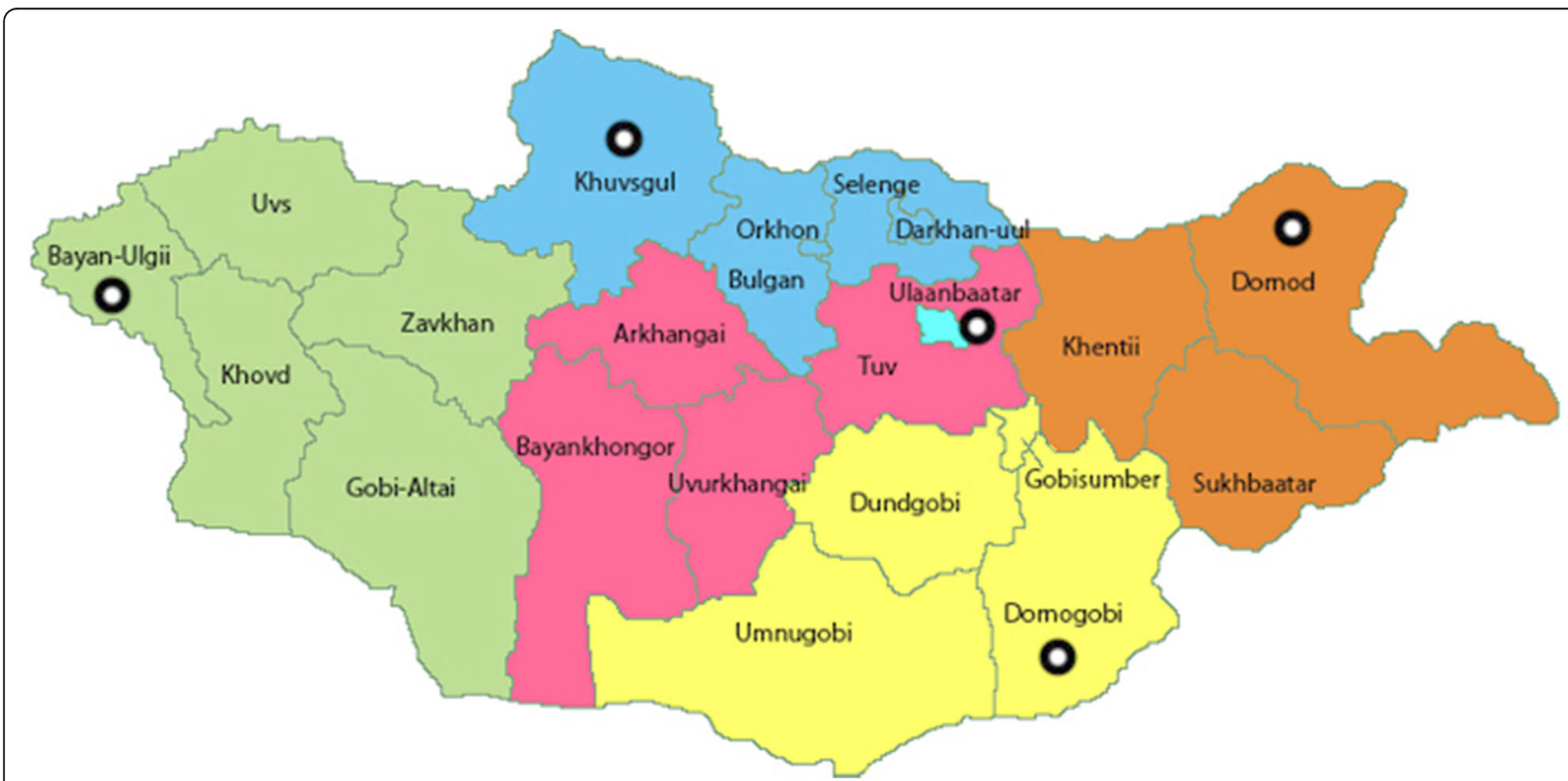

Fig. 1 Geographical map of Mongolia and selected regions based upon entry points to Mongolia (downloaded from Mongolia Map by Vemaps. com with authorization) 
retail pharmacies in urban areas $(n=1110,62.7 \%)$. When the samples were not available or there were insufficient samples, the study team randomly selected the next pharmacy entity to make up the samples. From each entity, the same brands, but different batches of pharmaceutical products were purchased and analysed.

Of note, Revolving Drug Funds (RDF) operate only in rural areas and 135 (7.6\%) were acquired from RDFs. Similarly, to other areas, the same brands but different batches of products were collected from RDFs.

More samples were purchased from wholesalers in urban areas when compared to their counterparts in rural areas $[(\mathrm{n}=210,11.9 \%$ vs $\mathrm{n}=60,3.4 \%, p=0.001)]$. Data regarding individual samples purchased from pharmacy entities in urban and rural areas are presented in Table 2. Samples of one brand could include different batch numbers, due to out-of-stock or unavailability.

\section{Visual inspection and authenticity Outer package}

In accordance with the drug registration requirements, an observational analysis of the outer package including the layout, print colour and information regarding the printed batch number, registration number, manufacturing, expiry dates were completed. Tablets and capsules were packaged in individual blisters, whereas powder for injection and infusion solutions were packed in sealed bottles, and bags. Of 179 substandard samples, 32 were the same brand but had different batch numbers (Table 3).

Officially accepted languages of package inserts are Mongolian, Russian or English. Predominantly, Mongolian and English were found, however a small number of the samples was found to be in other languages $(n=23,1.3 \%)$.

\section{Pharmacopoeial quality analysis}

There were 1770 samples of 15 different medicines analyzed for their quality. Of these 179 (10.1\%) samples failed pharmacopoeial tests. An analysis of substandard medicines indicated that the proportion of substandard locally produced medicines $(\mathrm{n}=105,5.9 \%)$ was higher than their imported equivalents $[(\mathrm{n}=74,4.2 \%), p=$ 0.0001]. The prevalence of substandard samples was approximately three times higher for domestic products than imported products $(n=195,18.7 \%$ vs $n=74,6.1 \%)$.

Approximately one-third of all sub-standard pharmacopoeial tests were related to assay $(n=73$, $30.8 \%$ ) and weight variation (Table 4). These results were mostly due to the sub-standard assay content in citramon-P (acetylsalicylic acid+acetaminophen+caffeine), $240 \mathrm{mg}+180+30 / 450 \mathrm{mg}$ tablets) and diclofenac $100 \mathrm{mg}$ tablets with non-compliant weight variation. Samples of omeprazole $20 \mathrm{mg}$ and amoxicillin $500 \mathrm{mg}$ failed due to dissolution test results.
For all 1770 samples, all mandatory tests required for drug registration in Mongolia were completed in this study. (Table 4).

\section{Registration status}

Of 1770 samples, 76 (4.3\%) were unregistered and the prevalence of unregistered samples was 3.8\% in Ulaanbaatar city and $5.8 \%$ in rural area, respectively. Sildenafil citrate $100 \mathrm{mg}$ tablets $(\mathrm{n}=26,34.2 \%)$ and amoxicillin trihydrate $500 \mathrm{mg}$ tablets $(\mathrm{n}=22,22.4 \%)$ were found to be the most frequently unregistered samples. All unregistered samples were imported medicines produced by 12 manufacturers from seven different countries.

The proportion of substandard samples were likely to be unregistered $(n=40,52.6 \%)$ when compared to their registered counterparts $(\mathrm{n}=139,8.2 \%)(p<0.0001)$. In addition, sildenafil citrate $100 \mathrm{mg}$ was found to be falsified $(\mathrm{n}=15,12.7 \%)$ and its manufacturer and country of origin were not identified. Samples did not pass the quantity, content uniformity and information on the outer packaging as well as the tablet appearance. (Fig. 2).

\section{Discussion}

This cross-sectional study investigated the quality of 1770 samples of 15 specific medicines collected from various types of pharmacy entities located in four districts of Ulaanbaatar city and four rural provinces in Mongolia. It was found that $10.1 \%$ of the total samples were substandard. In a comparison with a survey performed in 2012 [18], the proportion of substandard medicines had slightly decreased from 14.6 to $10.1 \%$ found in this study. However, the prevalence of substandard products was three times higher for locally manufactured products (18.6\%) than for imported counterparts (6.1\%). Local manufacturing of medicines is promoted in the NMPM and it is mainly to improve the access to essential medicines in Mongolia. However, implementation of good manufacturing practices (GMP) requires significant expenditure for pharmaceutical companies. Large companies operate on a scale that allows them to recover the costs of running high-quality factories, but this is not the case for smaller manufacturers in developing countries [34]. In India, a number of small manufacturers struggle to implement quality-assurance and quality-control procedures even with a large population. Similarly, a majority of locally produced cotrimoxazole were reported to be substandard when evaluated in Indonesia [35].

A systematic review on the prevalence of substandard/falsified medicines from 2007 to 2016 by means of electronic databases reported that it was $10.5 \%$ in low-middle income countries. The results in the WHO report are based on studies with the objective 
Table 2 Summary data of collected samples, their sources, strengths and dosage forms

\begin{tabular}{|c|c|c|c|c|c|c|c|}
\hline \multirow[t]{2}{*}{ Medicine's name, dosage, dose form } & \multicolumn{2}{|c|}{ Sampling area } & \multicolumn{3}{|c|}{ Pharmacy entity } & \multicolumn{2}{|c|}{ Sample source } \\
\hline & Urban & Rural & Wholesaler & Community pharmacy & RDF & Local & Import \\
\hline Acetaminophen, 500 mg/tab & 88 & 30 & 43 & 66 & 9 & 118 & 0 \\
\hline Acetylsalicylic acid, 81 mg/tab & 88 & 30 & 43 & 66 & 9 & 108 & 10 \\
\hline Amlodipine, 10 mg/tab & 88 & 30 & 43 & 66 & 9 & 49 & 69 \\
\hline Amoxicillin, 500 mg/tab & 88 & 30 & 43 & 66 & 9 & 45 & 73 \\
\hline Cefotaxime, $1 \mathrm{~g} / \mathrm{vial}$ & 88 & 30 & 43 & 66 & 9 & 14 & 104 \\
\hline Cetirizine, $10 \mathrm{mg} / \mathrm{tab}$ & 88 & 30 & 43 & 66 & 9 & 9 & 109 \\
\hline Ciprofloxacin, 500 mg/tab & 88 & 30 & 43 & 66 & 9 & 14 & 104 \\
\hline Citramon-P (Acetylsalicylic acid+acetaminophen+caffeine), 450 mg /tab & 88 & 30 & 43 & 66 & 9 & 102 & 16 \\
\hline Diclofenac sodium, 100 mg/tab & 88 & 30 & 43 & 66 & 9 & 73 & 45 \\
\hline Ibuprofen, 400 mg/tab & 88 & 30 & 43 & 66 & 9 & 3 & 115 \\
\hline Metronidazole, $0.5 \% / 100 \mathrm{ml} /$ infusion & 88 & 30 & 43 & 66 & 9 & 14 & 104 \\
\hline Nystatin, 5,000,000 IU/tab & 88 & 30 & 43 & 66 & 9 & 0 & 118 \\
\hline Omeprazole, 20 mg/tab & 88 & 30 & 43 & 66 & 9 & 0 & 118 \\
\hline Panangin (Aspartic Acid, L- potassium and magnesium), 298 mg/tab & 88 & 30 & 43 & 66 & 9 & 0 & 118 \\
\hline Sildenafil citrate, 100 mg/tab & 88 & 30 & 43 & 66 & 9 & 16 & 102 \\
\hline Total $(N=1770)$ & 1320 & 450 & 645 & 990 & 135 & 565 & 1205 \\
\hline
\end{tabular}

to quantify quality problems regarding specific drug classes, including antimalarials and antibiotics [36].

In this study, most of all failed tests were due to assay, content uniformity, dissolution and disintegration. These failures were related to citramon-P (acetylsalicylic acid+acetaminophen+caffeine), $240 \mathrm{mg}+180+30 / 450 \mathrm{mg}$ tablets), omeprazole $20 \mathrm{mg}$, ciprofloxacin $500 \mathrm{mg}$ and diclofenac sodium, $100 \mathrm{mg}$ tablets owing to poor weight uniformity. Samples of amoxicillin $500 \mathrm{mg}$ and omeprazole $20 \mathrm{mg}$ failed due to dissolution test results in this study.

Apart from being substandard or falsified at the manufacturing stage, the quality of pharmaceutical products is affected by inappropriate storage and transportation conditions during the supply chain [37].

The Mongolian climate is known to be very harsh, with temperatures below $-30{ }^{\circ} \mathrm{C}$ in winter. Some rural areas are hot $\left(>30^{\circ} \mathrm{C}\right)$ in summer. Medicines can deteriorate during storage and transportation in extreme weather conditions and degraded medicines might be

Table 3 Assessment of the outer packaging for regulatory compliance

\begin{tabular}{lll}
\hline Description & Present $\mathrm{n}(\%)$ & Absent $\mathrm{n}(\%)$ \\
\hline Registration number & $1694(95.7 \%)$ & $76(4.3 \%)$ \\
Batch number & $1761(99.2 \%)$ & $15(0.9 \%)$ \\
Manufacturing date & $1761(99.5 \%)$ & $15(0.9 \%)$ \\
Expiration date & $1761(99.5 \%)$ & $15(0.9 \%)$ \\
\hline
\end{tabular}

distributed in the market $[38,39]$. All standard protocols on transportation and storage requirements were complied with during the sample collection and quality assurance was maintained throughout study, including data analysis. However, the samples were collected from different pharmacy entities, meaning that there might be potential risks during distribution or transportation until pharmaceutical products are delivered to each pharmacy entity. Hence, more information to identify the impact of climate during supply and storage chain on drug quality needs to be further investigated.

Good pharmacy practice is promoted by the $\mathrm{MOH}$ and enforced by the GASI. However, due to financial constraints and limited human resources, strict quality control measures are yet to be implemented [40, 41].

In this study, one fake sample of sildenafil citrate 100 mg was found. The quantitative content of active ingredient was $45.3-65.4 \%$ well below the pharmacopoeial limit (95-105\%). Problems with phosphodiesterase type 5 inhibitors (PDE5) have been reported elsewhere, for example an Italian survey on the PDE5 medicines was completed between 2005 and 2011 [42]. It found that $24.0 \%$ of the analyzed samples were counterfeit and $54.0 \%$ were illegal medicines. In $12.0 \%$ of the cases an intermediate classification (illegal/counterfeit) was assigned, whereas only $7.0 \%$ of the samples were original [42].

The study showed a decreased prevalence of unregistered medicines, when compared with the previous findings [18]. This could be due to the MOH's efforts to strengthen the drug registration as well as development 
Table 4 Number of samples that failed each pharmacopoeial test

\begin{tabular}{|c|c|c|c|c|c|c|c|c|}
\hline Medicine's name / Test parameter & Appearance & $\begin{array}{l}\text { Weight } \\
\text { variation }\end{array}$ & Dissolution & $\begin{array}{l}\text { Friability } \\
\text { test }\end{array}$ & Disintegration & $\begin{array}{l}\text { Assay of active } \\
\text { ingredient }\end{array}$ & $\begin{array}{l}\text { Total tests } \\
\text { failed }\end{array}$ & $\begin{array}{l}\text { Total } \\
\text { samples } \\
\text { failed }\end{array}$ \\
\hline Acetaminophen 500 mg & 17 & 8 & $\mathrm{p}$ & 6 & $p$ & 4 & 35 & 23 \\
\hline $\begin{array}{l}\text { Acetylsalicylic } \\
\text { acid+paracetamol+caffeine } 450 \text { mg/ } \\
\text { tab }\end{array}$ & $\mathrm{p}$ & $p$ & $\mathrm{p}$ & $\mathrm{p}$ & 25 & 41 & 66 & 41 \\
\hline Amlodipine $10 \mathrm{mg}$ & $\mathrm{p}$ & 8 & $\mathrm{p}$ & $\mathrm{p}$ & $p$ & $\mathrm{p}$ & 8 & 8 \\
\hline Amoxicillin 500 mg & $\mathrm{p}$ & 4 & 23 & $\mathrm{p}$ & $p$ & $p$ & 27 & 27 \\
\hline Ciprofloxacin $500 \mathrm{mg}$ & $p$ & 11 & $p$ & $\mathrm{p}$ & $p$ & 6 & 17 & 17 \\
\hline Diclofenac Sodium 100 mg/tab/cap & $\mathrm{p}$ & 22 & $\mathrm{p}$ & $\mathrm{p}$ & $p$ & 14 & 36 & 22 \\
\hline Ibuprofen 400 mg & 3 & 2 & $p$ & $\mathrm{p}$ & $p$ & $p$ & 5 & 5 \\
\hline Metronidazole $0.5 \% / 100 \mathrm{ml}$ & $p$ & $\mathrm{n} / \mathrm{a}$ & $\mathrm{n} / \mathrm{a}$ & $\mathrm{n} / \mathrm{a}$ & $\mathrm{n} / \mathrm{a}$ & 3 & 3 & 3 \\
\hline Nystatin $500,000 \mathrm{IU}$ & 10 & $p$ & $\mathrm{p}$ & $\mathrm{p}$ & $p$ & $p$ & 10 & 10 \\
\hline Omeprazole 20 mg & $p$ & 7 & 7 & $\mathrm{p}$ & $p$ & $p$ & 14 & 7 \\
\hline Sildenafil citrate 100 mg & $\mathrm{p}$ & 11 & $\mathrm{p}$ & $\mathrm{p}$ & $p$ & 5 & 16 & 16 \\
\hline Total & & & & & & & 237 & 179 \\
\hline
\end{tabular}

Note: $n$ /a-not applicable, $\mathrm{p}$ - passed the required test

of an online database "Licemed" to check and verify drug information. However, discrepancies in outer packaging and information on package inserts can potentially contribute to the inappropriate use of medicines [43].

Research shows that multi-faceted interventions including a mix of regulations, training of inspectors, publicprivate collaborations and legal enforcement actions are useful in combating substandard and falsified medicines [44]. At the time of writing the manuscript, the regulation of drug registration has been revised and approved by the Mongolian Government [45]. It is envisaged that with revised legal requirements, implementation and enforcement of quality assurance will be improved in Mongolia.

\section{Limitations}

The study aimed to provide a representative sampling in location and size, but only $6.0 \%$ of all pharmacy entities, including retail pharmacies, wholesalers and RDFs were included. However, high risk sites and the population size were considered for site selection. A random selection method was employed in selecting the pharmacy entities.

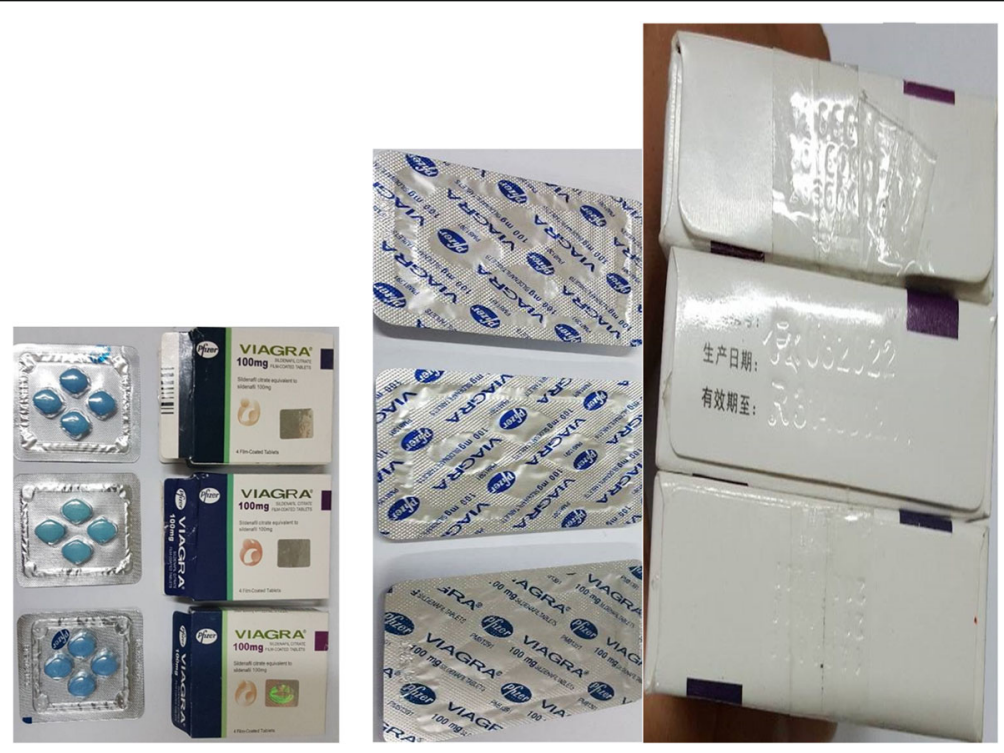

Fig. 2 Fake Viagra $100 \mathrm{mg}$ (Sildenafil citrate $100 \mathrm{mg}$ ) samples 
Secondly, samples with suspicious packaging and labeling were sent to the representative offices of the manufacturers for confirmation whether if the suspected product was their product and discrepancies between the suspected and genuine product were verified. However, falsified products can be produced in the same facility as the licensed product. This might be a limitation.

\section{Conclusion}

Overall the national law coordination and law enforcement on registering medicines is in place in Mongolia. Nevertheless, echoing previous findings, the current study results suggest that substandard and falsified medicines are still prevalent in Mongolia. Prevalence of low quality medicines indicate that licensing of manufacturing plants and pharmacy outlets is not fully effective.

\section{Recommendation}

Prevalence of falsified medicines is a major public health problem because it would result in avoidable morbidity, mortality and drug resistance. Regulatory authorities in Mongolia need to enhance their commitment to strengthening licensing of local manufacturers, importers and their GMP compliance. Licensing of local manufacturers should be upgraded to international standards and more stringent rules, including routine quality control tests should be performed to ensure the quality assurance.

\section{Abbreviations}

ADB: Asian Development Bank; ANAB: American National Accreditation Board; ANSI-ASQ: American National Standards Institute and American Society for Quality; BP: British Pharmacopoeia; cap: Capsule; CP: Chinese Pharmacopoeia; EML: Essential Medicines List; EP: European Pharmacopoeia; g: Gramm; GASI: Generalized Agency for Specialized Inspection;

IU: International Unit; mg: Milligram; ml: Millilitre; MNP: Mongolian National Pharmacopoeia; MNUMS: Mongolian National University of Medical Sciences; $\mathrm{MOH}$ : Ministry of Health; NMPM: National Medicines Policy of Mongolia; RDF: Revolving Drug Fund; Tab: Tablet; WHO: World Health Organization

\section{Acknowledgements}

Authors would like to acknowledge all directors and staff of participating pharmacy outlets for their help and support to conduct this study.

\section{Authors' contributions}

GD, KD, BS, TS conceived of, carried out the study, drafted and revised the manuscript. BE, EB, GD, AJ, OL, DD participated in the design and coordination of the study and revised the manuscript. GD, KD, BS, TS, BE, EB, GD, AJ, OL, DD contributed equally to this work. The authors read and approved the final manuscript.

\section{Funding}

The study was conducted under the grant TA8967-MON: Improving Access to Affordable Medicines in Public Hospitals and administered by the ADB. The funder had no role in the design of the study and collection, analysis, and interpretation of data and in writing the manuscript.

\section{Availability of data and materials}

The datasets used and/or analyzed during the current study is from the corresponding author on reasonable request.

\section{Ethics approval and consent to participate}

The study protocol was introduced to the Scientific Council, the School of Pharmacy, Mongolian National University of Medical Sciences and deemed as not necessary as the study didn't involve any patient data (Protocol No. 2/ 3/17).

\section{Consent for publication}

Not applicable.

\section{Competing interests}

The authors declare that they have no competing interests.

\section{Author details}

${ }^{1}$ School of Pharmacy, Mongolian National University of Medical Sciences, S. Zorig street, Ulaanbaatar, Sukhbaatar District 14210, Mongolia. ${ }^{2}$ School of Pharmacy, Curtin University of Technology, GPO Box U1987, Perth 6845, Western Australia. ${ }^{3}$ School of Public Health, Mongolian National University of Medical Sciences, S. Zorig street, Ulaanbaatar, Sukhbaatar District 14210, Mongolia. ${ }^{4}$ Asian Development Bank, Mongolia Resident Mission, Ulaanbaatar, Sukhbaatar District 14210, Mongolia.

Received: 19 February 2020 Accepted: 11 May 2020

Published online: 20 May 2020

\section{References}

1. Caudron JM, Ford N, Henkens M, Mace C, Kiddle-Monroe R, Pinel J. Substandard medicines in resource-poor settings: a problem that can no longer be ignored. Trop Med Int Health. 2008;13(8):1062-72.

2. Newton PN, Green MD, Fernández FM. Impact of poor-quality medicines in the 'developing'world. Trends Pharmacol Sci. 2010;31(3):99-101.

3. Mackey TK, Liang BA. The global counterfeit drug trade: patient safety and public health risks. J Pharm Sci. 2011;100(11):4571-9.

4. Liang BA. Fade to black: importation and counterfeit drugs. Am J Law Med. 2006;32(2-3):279-323.

5. World Health Organization. Substandard and falsified medical products; 2018.

6. Ozawa S, Evans DR, Bessias S, Haynie DG, Yemeke T, Laing SK, et al. Prevalence and estimated economic burden of substandard and falsified medicines in low-and middle-income countries: a systematic review and meta-analysis. JAMA Netw Open. 2018;1(4):e181662-e.

7. World Health Organization. A study on the public health and socioeconomic impact of substandard and falsified medical products. Geneva: World Health Organization; 2017.

8. Nayyar GM, Breman JG, Newton PN, Herrington J. Poor-quality antimalaria drugs in Southeast Asia and sub-Saharan Africa. Lancet Infect Dis. 2012; 12(6):488-96.

9. Almuzaini T, Choonara I, Sammons H. Substandard and counterfeit medicines: a systematic review of the literature. BMJ Open. 2013;3(8): e002923.

10. Kelesidis T, Falagas ME. Substandard/counterfeit antimicrobial drugs. Clin Microbiol Rev. 2015:28(2):443-64.

11. Buckley GJ, Gostin LO. Countering the problem of falsified and substandard drugs. Washington DC: National Academies Press; 2013.

12. World Health Organization. WHO report on surveillance of antibiotic consumption: 2016-2018 early implementation; 2018. Available from: https://apps.who.int/iris/bitstream/handle/10665/277359/9789241514880eng.pdf.

13. Ministry of Health of Mongolia. Report on intensive surveillance of counterfeit medicines in Mongolia; 2006.

14. The Government of Mongolia. National Drug Policy of Mongolia; 2014

15. Dorj G, Sunderland B, Sanjjav T, Dorj G, Gendenragchaa B. Availability, affordability and costs of pediatric medicines in Mongolia. BMC Pediatr. 2018;18(1):149.

16. Munkhdelger C. Survey of medicine prices, availability, affordability and price components in Mongolia; 2012

17. Ministry of Health of Mongolia. Rapid track surveillance of quality of medicines in Mongolia; 2002.

18. Khurelbat D, Dorj G, Bayarsaikhan E, Chimedsuren M, Sanjjav T, Morimoto T, et al. Prevalence estimates of substandard drugs in Mongolia using a random sample survey. SpringerPlus. 2014;3(1):709. 
19. Togoobaatar G, Ikeda N, Ali M, Sonomjamts M, Dashdemberel S, Mori R, et al. Survey of non-prescribed use of antibiotics for children in an urban community in Mongolia. Bull World Health Organ. 2010;88:930-6.

20. Dorj G, Hendrie D, Parsons R, Sunderland B. An evaluation of prescribing practices for community-acquired pneumonia (CAP) in Mongolia. BMC Health Serv Res. 2013;13(1):379.

21. World Health Organization. Guidelines on the conduct of surveys of the quality of medicines. 2015; 2016.

22. World Health Organization. WHO expert committee on specifications for pharmaceutical preparations: fiftieth report. Geneva: World Health Organization; 2016.

23. World Health Organization. WHO draft guidance on testing of "suspect" spurious/falsely-labelled/falsified/counterfeit medicines 2016 [cited 2019 16th January]. Available from: http://www.who.int/medicines/areas/quality_safety/ quality_assurance/Post-Meeting_SFFC_Testing_DraftGuidance_QAS15-634.pdf.

24. ANSI-ASQ National Accreditation Board. Certificate of accreditation; 2019.

25. World Health Organization. Counterfeit drugs: guidelines for the development of measures to combat counterfeit drugs; 1999

26. The Government of Mongolia. The law on medicines and medical devices of Mongolia; 1998

27. The Government of Mongolia. The law on medicines and medical devices of Mongolia (revised); 2010.

28. United States Pharmacopoeia (USP). Tool for Visual Inspection of Medicines, 2005.

29. National Drug Registry of Mongolia "Licemed". 2018 [cited 23, September, 2018]. Available from: http://licemed.mohs.mn.

30. General Authority for Border Protection of Mongolia. National Border of Mongolia; 2018.

31. Ministry of Health Mongolia. Health indicators of Mongolia-2016; 2016.

32. Ministry of Health Mongolia. The 8th essential drug list of Mongolia; 2017.

33. Dorj G, Sunderland B, Sanjjav T, Dorj G, Gendenragchaa B. Drug pricing and reimbursement decision making systems in Mongolia. J Pharmaceutical Policy Practice. 2017;10(1):11.

34. Kaplan W, Laing R. Local production of pharmaceuticals: industrial policy and access to medicines, an overview of key concepts, issues and opportunities for future research. Washington, DC: World Bank; 2005.

35. Hadi U, van den Broek P, Kolopaking EP, Zairina N, Gardjito W, Gyssens IC. Cross-sectional study of availability and pharmaceutical quality of antibiotics requested with or without prescription (over the counter) in Surabaya, Indonesia. J BMC Infect Dis. 2010;10(1):203.

36. World Health Organization. A study on the public health and socioeconomic impact of substandard and falsified medical products. Geneva: World Health Organization; 2017. Contract No.: WHO/EMP/RHT/2017.02.

37. Newton PN, Amin AA, Bird C, Passmore P, Dukes G, Tomson G, et al. The primacy of public health considerations in defining poor quality medicines. PLoS Med. 2011;8(12):e1001139.

38. Lucas TI, Bishara RH, Seevers RH. A stability program for the distribution of drug products. J Pharm Technol. 2004;28:68-73.

39. Khan MH, Hatanaka K, Sovannarith T, Nivanna N, Casas LCC, Yoshida N, et al. Effects of packaging and storage conditions on the quality of amoxicillinclavulanic acid-an analysis of Cambodian samples. J BMC Pharmacol Toxicol. 2013;14(1):33.

40. Ministry of Health of Mongolia. Report on drug regulatory system assessment of Mongolia; 2011.

41. Ministry of Health of Mongolia. Drug safety and human resources subsectors analysis; 2010.

42. Gaudiano MC, Manna L, Rodomonte AL, Bartolomei M, Bertocchi P, Gallinella B, et al. A survey on illegal and counterfeit medicines for the treatment of erectile dysfunctions in Italy. J Sex Med. 2012;9(8):2130-7.

43. Yoshida N, Khan MH, Tabata H, Dararath E, Sovannarith T, Kiet HB, et al. A cross-sectional investigation of the quality of selected medicines in Cambodia in 2010. BMC Pharmacol Toxicol. 2014:15(1):13.

44. El-Jardali F, AkI EA, Fadlallah R, Oliver S, Saleh N, El-Bawab L, et al. Interventions to combat or prevent drug counterfeiting: a systematic review. BMJ Open. 2015;5(3):e006290.

45. Ministry of Health Mongolia. Registration regulation of drugs, raw materials and biologically active substances (revised). Ulaanbaatar: Centre for Health Deelopment, Ministry of Health Mongolia; 2019.

\section{Publisher's Note}

Springer Nature remains neutral with regard to jurisdictional claims in published maps and institutional affiliations.

\section{Ready to submit your research? Choose BMC and benefit from:}

- fast, convenient online submission

- thorough peer review by experienced researchers in your field

- rapid publication on acceptance

- support for research data, including large and complex data types

- gold Open Access which fosters wider collaboration and increased citations

- maximum visibility for your research: over $100 \mathrm{M}$ website views per year

At BMC, research is always in progress.

Learn more biomedcentral.com/submissions 